University of Nebraska - Lincoln

DigitalCommons@University of Nebraska - Lincoln

August 2006

\title{
Race and Gender Matter: Refining Models of Legislative Policy Making in State Legislatures
}

\author{
Byron D. Orey \\ borey2@unl.edu \\ Wendy Smooth \\ The Ohio State University \\ Kimberly S. Adams \\ East Stroudsburg University \\ Kisha Harris-Clark \\ Clark Atlanta University and Government Accountability Office
}

Follow this and additional works at: https://digitalcommons.unl.edu/poliscifacpub

Part of the Political Science Commons

Orey, Byron D.; Smooth, Wendy; Adams, Kimberly S.; and Harris-Clark, Kisha, "Race and Gender Matter: Refining Models of Legislative Policy Making in State Legislatures" (2006). Faculty Publications: Political Science. 20.

https://digitalcommons.unl.edu/poliscifacpub/20

This Article is brought to you for free and open access by the Political Science, Department of at DigitalCommons@University of Nebraska - Lincoln. It has been accepted for inclusion in Faculty Publications: Political Science by an authorized administrator of DigitalCommons@University of Nebraska - Lincoln. 


\title{
Race and Gender Matter: Refining Models of Legislative Policy Making in State Legislatures
}

\author{
Byron D'Andrá Orey, University of Nebraska, Lincoln \\ Wendy Smooth, The Ohio State University \\ with \\ Kimberly S. Adams, East Stroudsburg University \\ Kisha Harris-Clark, Clark Atlanta University \\ and Government Accountability Office
}

\begin{abstract}
SUMMARY. In this article, we explore the degree to which African American state legislators have been able to translate election to office into substantive representation. We are particularly interested in the impact of race and gender on the likelihood of legislative bill submission and passage. While previous studies have focused on inter-group representation, our analysis examines intra-group representation by disaggregating race, gender, and party identification. By doing so, we are able to capture the intragroup variation between various groups such as black Democratic men and black Democratic women and white Democratic women and white Republican women. Using the case of Mississippi, the state with the highest number of black elected officials, we examine the legislator's
\end{abstract}

[Haworth co-indexing entry note]: "Race and Gender Matter: Refining Models of Legislative Policy Making in State Legislatures." Orey, Byron D'Andrá et al. Co-published simultaneously in Journal of Women, Politics \& Policy (The Haworth Press, Inc.) Vol. 28, No. 3/4, 2006, pp. 97.119; and: Intersectionality and Politics: Recent Research on Gender, Race, and Political Representation in the United States (ed: Carol Hardy-Fanta) The Haworth Press, 2006, pp. 97-119. Single or multiple copies of this article are available for a fee from The Haworth Document Delivery Service [1-800-HAWORTH, 9:00 a.m. - 5:00 p.m. (EST). E-mail address: docdelivery@haworthpress.com].

Available online at http://jwpp.haworthpress.com

(C) 2006 by The Haworth Press, Inc. All rights reserved. doi:10.1300/J501v28n03_05 
propensity to introduce and pass progressive legislation. We employ logistic regression using cluster standard errors. The results reveal that a progressive bill is more likely to be introduced when a black woman serves as the primary sponsor, as compared to other members in the state legislature. However, contrary to our expectations, African American women are not significantly less likely to get their bills passed when compared to their colleagues. These findings point out the need to build more defined models of legislative policymaking that are attentive to the intersections of race and gender as political categories of significance. doi: 10.1300/J501 v28n03 05 [Article copies available for a fee from The Haworth Document Delivery Service: 1-800-HAWORTH.E-mail address: <docdelivery@ haworthpress.com> Website: <http://www.HaworthPress.com> ( 2006 by The Haworth Press, Inc. All rights reserved.]

KEYWORDS. African American legislators, African American women legislators, women legislators, intersectionality, policymaking, representation, descriptive representation, substantive representation

\section{INTRODUCTION}

Since the passage of the Voting Rights Act of 1965 (VRA), we have witnessed an increase in political participation among African Americans. The Voting Rights Act of 1965 initially sought to remedy the systemic exclusion of African Americans from the body politic by repealing literacy tests and poll taxes as prerequisites to voting. The repeal of these barriers marked a significant transition for African Americans, particularly in the Deep South. It allowed for unprecedented registration of black voters and created the opportunity for African Americans to elect the candidates of their choice. Following the passage of the VRA, African Americans moved from virtually no meaningful involvement in politics and no black representation to a significant rise in the number of black elected officials in the South, particularly at the state and local levels (Bositis 1999).'

Shortly following the passage of the Voting Rights Act, 1,469 African Americans served in elected office from the national to local levels, but only 160 were African American women. As the numbers of African American officeholders increased, African American women were central to that growth. By 2001, there were a reported 9,101 black elected officials and 3,220 were African American women. Since 1990 however, African American women have outpaced African American men in achieving elective office. In fact, Bositis (2001) attributes the growth in the number of black elected officials over the last decade tc African American women. This reverses the earlier trends of the 1970 immediately following the passage of the Voting Rights Act when 82 percent of the growth in black elected officials was attributed to the increase in the number of African American men (Bositis 2001).

Though the numbers of African American women in state legislatures still remain small, they have steadily increased while the overall numbers of women in state legislatures have reached a plateau. Between 1971 and 1996, the numbers of women elected to state legislatures grew steadily. However, by the mid-1990s, the overall rate of growth for women elected to state legislatures actually began to stagnate, a phenomenon that remains today (Sanbonmatsu 2005). Yet, for African American women and other women of color, their numbers continued to increase In 1998, for example, only 168 African American women served as state legislators, and by 2004 their numbers increased by 47 women amounting to a 28 percent increase (Smooth 2005).

Despite the increase in African American women elected to state legislatures, we have very limited understandings of their behavior as elected officials. Both the black politics and the women in politics literatures have failed to examine the impact of the intersection of race and gender in politics. Studies focusing on either African Americans or women have, for the most part, studied the experiences of African American men or white women, thereby failing to acknowledge the reality that not all African Americans are men and not all women are white. Such approaches to studying race and gender have traditionally rendered women of color invisible in their analyses (Hull et al. 1982). In early studies of African American women in politics, they appeared to behave differently from their counterparts leading Baxter and Lansing (1981) to conclude that their behavior could not be accurately predicted by models of African American men or white women's political behavior. Hawkesworth (2003) argues that such disparate treatments of the intersection of race and gender have failed to account for the persistence of marginalization reported by women of color in legislative institutions. Such generalizations, we argue, may have led to incomplete analyses that prompt researchers to make broad generalizations that their data may not actually support.

In this study, we focus on the differences among groups of legislators to discern the impact of the intersection of race and gender on representation in state legislatures. We begin this analysis by assessing the 
agenda-setting activities of African American legislators and asking whether or not they are more likely than their white counterparts to introduce progressive legislation. We further question whether African American women establish legislative agendas that differ from African American men. Finally, we ask a series of questions regarding the success of African American legislators in passing legislation and again disaggregate this data by gender to discern if the intersection of race and gender results in differing experiences with legislative bill success. This approach moves toward empirically testing the well-theorized construct of intersectionality, which asserts that no singular aspect of one's identity can fully explain the ways in which one experiences the world. Instead, as scholars of black feminism have argued, African American women experience their race and gender simultaneously with each informing the other in concert (Lorde 1984; King 1988; Collins 1990, 2000; Crenshaw 1991). Informed by this perspective, we disaggregate the data according to race, gender and political party as a means of more fully understanding the dynamics informing representation in state legislatures.

\section{DESCRIPTIVE AND SUBSTANTIVE REPRESENTATION}

The concept of representation has been an important and useful framework for understanding the entry of women and men of color into governing bodies. Pitkin's (1967) seminal work on representation distinguishes four types of representation. Representation, according to Pitkin's typology, includes descriptive representation in that legislators and those they represent share similar physical traits such as ethnicity, race or gender; symbolic representation in that legislators have the confidence of those they represent and are trusted; formal representation in that legislators are selected according to the formal rules of an institution; or substantive representation in that legislators deliver policy outputs that are in the interest of those they represent. Here, we are concerned with both descriptive and substantive forms of representation. Given the historic increase in the number of black elected officials, questions abound regarding their effectiveness in representing African American interests. These questions become even more complex once we account for African American women's representation of women's interests. Central to this debate is whether electing officials that are descriptively representative of these groups results in increasing policy outputs that also are beneficial to these groups. Following the passage of the Voting Rights Act of 1965, African
Americans clearly experienced an increase in descriptive representation, but it is less clear whether descriptive representation has resulted in substantive representation. Scholars debate the extent to which descriptive representation results in an increase in substantive representation for African Americans (Swain 1993; Whitby 1998; Mansbridge 1999; Tate 2004). These questions regarding representation are even more complex given the ever-growing body of literature suggesting that a legislator's gender impacts the policymaking process (Thomas 1994; Kathlene 1994, 1995; Norton 1995; Rosenthal 1998) and impacts the ways in which legislators define their constituency (Reingold 2000 Carroll 2002; Swers 2002). Despite the extensive focus on representation, few scholars have examined the intersection of race and gender and its impact on representation, so questions remain regarding how any women of color define their constituency and represent the interests of that group. Among black politics and women and politics scholars, despite considering African Americans and women as mutually exclusive groups, they reach similar conclusions that African Americans (Hamm, Harmel, and Thompson 1983; Miller 1990; Parker 1990; Nelson 1991; Bratton and Haynie 1999) and women (Saint-Germain 1989; Carrol, Dodson, and Mandel 1991; Thomas and Welch 1991; Kathlene 1994; Bratton and Haynie 1999) do make a difference in state policymaking.

The questions that arise, then, are what is the nature of the difference these groups make in the policymaking process? Have African Americans been more active than white legislators, less active, or equally active in introducing progressive legislation? More specifically, have African American women, African American men, white women, or white men been more active in introducing progressive legislation? Likewise, which groups have been more or less successful in passing their initiatives? With the increase in the numbers of African American women serving as state legislators, we are able to raise questions regarding the impact of both race and gender on the policymaking process. Attention to intragroup differences along the lines of race, gender, and political party is likely to enrich our understandings of legislative activity. It is possible that gender differences exist among African Americans and racial differences among women that impact the types of bills they introduce as well as the chances of the legislation passing. For example, women legislators are more likely than men to consider women's issues a top priority (SaintGermain, 1989; Carroll 1991) and are more likely to introduce legislation reflective of these priorities (Barrett 1995). Yet, African American women are likely to differ from white women in light of the distinctive policy 
priorities of African Americans. Our analysis increases our understanding of how these differences among groups and across groups in the legislature impact the policymaking process.

Understanding the intersection of race and gender and its impact on descriptive and substantive representation is all the more critical given studies of African American women in politics which suggest that they experience a "double disadvantage" (Darcy and Hadley 1988; Moncrief, Thompson, and Schuman 1991) as elected representatives given the pervasiveness of both racism and sexism in legislatures (Barrett 1997; Hedge, Button, and Spear 1996; Smooth 2001; Hawkesworth 2003).

\section{AFRICAN AMERICANS \\ AND DISTINCTIVE POLICY INTERESTS}

Given our interest in the relationship between descriptive and substantive representation, we are concerned with the substantive content of African American legislators' bills as well as their legislative success. Therefore, we first question whether African American legislators are more likely than their white counterparts to introduce progressive legislation in the interest of blacks.

Studies of African American legislators suggest that from their first entry into state legislatures their agendas were formulated in relationship to the needs and interests of the African American community. In an early study of African Americans in the California state legislature, Sokolow (1971) found that African American legislators introduced a large number of the bills in the areas of health, education, crime, and welfare. These issue areas are in keeping with social and economic issues impacting the African American community given the fact that African Americans are diagnosed as having unique health concerns (Kahn et al. 1994; Williams and Collins 1996; Woods 1996), are more likely to encounter poverty and employment discrimination (Hacker 1992; Massey and Denton 1993), face housing discrimination, and be victims of criminal acts (Hacker 1992; Massey and Denton 1993) when compared to their white counterparts.

Scholars also find that there are racial differences in political opinions and behavior, in that; traditionally, African Americans are more progressive, more likely to vote for Democrats, and more likely to favor social programs (Brady and Sniderman 1985; Shapiro and Mahajan 1986). African Americans also tend to be more supportive of affirmative action (Kinder 1994). According to Dawson (1994), these attitudes are rooted in blacks' linked fate to other blacks. In other words, because of their shared historical experiences (e.g., economic subjugation), blacks tend to share a common fate, regardless of their class status (Tate 1993), believing that what happens to African Americans as a group has an impact on their individual lives. Most recent data on black public opinion suggest that the liberal policy agendas of black lawmakers are, on the one hand, reflective of black public opinion and, at the same time, shape black interests. In Tate's (2004) most recent work, she finds that black members of Congress are more progressive on social issues than blacks in general, as reported in public opinion surveys. According to the $\mathrm{Na}$ tional Black Election Study, blacks in 1996 were somewhat more conservative on social policy issues in comparison to their opinions in 1984. The relationship between black public opinion and black representation is clearly complex and warrants ongoing examination.

We can expect that African American legislators will continue in the tradition of representing a distinctive policy agenda that is informed by liberal progressive politics, and their legislation will continue to bring to the legislative agenda a set of under-represented opinions and experiences. Parker (1990) suggests that determining whether African American legislators have been relevant to the passage of progressive legislation in Mississippi requires "an analysis of votes on critical bills in each session since 1979" (134). To be sure, our analysis does not examine every critical bill proposed dating back to 1979 . We do, however, analyze the legislative proposals from the 1988-89 and 1998-99 legislative sessions to determine the impact of African American legislators on progressive legislation. ${ }^{2}$

While African Americans are likely to introduce legislation relevant to these traditional black interests, their effectiveness in successfully passing such legislation is still at question. Given the propensity of African American legislators to form distinctive and cohesive voting groups (Hamm, Harmel, and Thompson 1983), it is reasonable to expect, given their small number in proportion to the entire legislature, that African Americans in the Mississippi legislature will vote cohesively on those bills deemed to be progressive for African Americans. However, we can also expect that, given the prevalence of racially polarized voting in the electorate, which is likely mirrored in the legislature, that white legislators will also adopt such voting blocs. Therefore, because white legislators constitute a majority, we expect African American legislators to be less likely to achieve passage of their bills when compared to their white colleagues. For example, Orey (2000) finds that in 1987, white legislators in Mississippi were more than twice as likely to successfully pass 
legislation when compared to their black colleagues. In 1988, the success rate for African American legislators was even more dismal as they passed only five percent of their bills, compared to 21 percent for white legislators. Formally, we consider the following hypotheses:

Hypothesis 1: The likelihood of passage of a progressive bill is expected to increase when an African American legislator introduces a bill, compared to when a white legislator introduces a bill.

Hypothesis 2: A bill will be less likely to pass when an African American legislator introduces a bill, than when a white legislator introduces a bill.

\section{THE DOUBLE DISADVANTAGE HYPOTHESIS}

Scholars have written extensively on the impact of women on the public policymaking process and as well scholars have focused on the impact of race, yet few scholars have focused on the nexus of race and gender. Many of these scholars assume that African American women will perform as other women in legislative institutions, or as African American men, but few scholars have attempted to address these assumptions through empirical analyses (Barrett 1995). There is much in the literature to suggest that African American women have experiences that differ from both African American men and white women in politics. Baxter and Lansing (1981) surmised that African American women's political behavior could not be accurately predicted based on models of African American men or white women. In light of the high levels of political participation by African American women as voters, they concluded that their voter participation suggested that they be investigated as a distinct group differing in political behavior from both African American men and white women (Baxter and Lansing 1981). Indeed, African American women have turned out to vote in higher numbers than African American men since the midterm elections of 1974 (Williams 2001). Likewise, as candidates, African American women differ from their counterparts. For example, African American women have proven to be more politically ambitious in terms of seeking office than white women (Darcy and Hadley 1988). Though African American women in elected office are not represented in proportion to their numbers in the general population, since the 1970s they have composed a higher proportion of African American elected officials at all levels of government than white women have composed of white elected officials (Darcy and Hadley 1988; Williams 2001). Those African American women elected to office often come to their positions more prepared when compared to their colleagues in terms of the prestige of their former occupation and their educational preparedness (Prestage 1977; Darcy and Hadley 1988; Moncrief, Thompson, and Schuhmann 1995; Williams 2001).

Scholars are puzzled by African American women's political participation in that, despite encountering the duality of racism and sexism, they remain viable actors in the political world (Darcy and Hadley, 1988). Several authors conclude that experiencing the "double disadvantage" of racism and sexism contributes to African American women bringing a unique perspective to politics that differs from other groups (Darcy and Hadley, 1988; Moncrief et al. 1991). As Collins (1991) argues, black women's epistemological standpoint is developed from "those experiences and ideas shared by African American women that provide a unique angle of vision on self, community and society" (22). In her work on state legislators, Barrett (1995) provides further evidence of this shared perspective among African American women by examining their policy priorities. She concludes that African American women serving in state legislators are ideologically homogeneous and coalesce around policy agenda items that have strong implications for African Americans. African American women show coherence across states in their legislative policy priorities, which include education, healthcare, economic development, and unemployment. Essentially, African American women state legislators are invested in a progressive policy agenda. While these legislators have clearly carved out a policy niche, their progressive policy agendas may negatively impact their success in passing legislation (Barrett 1995).

In their work on bill sponsorship, Bratton and Haynie (1999) report a relationship between bill sponsorship and a legislator's gender and race. In comparing gender and race groups, they find that women are more likely to introduce women interest bills when compared to men, and blacks are more likely to introduce black interest bills when compared to whites. However, based on their findings, black women are less likely to introduce black interest bills and women interest bills. These findings run counter to previous studies, particularly those concluding that African American women legislators' policy agendas incorporate both their gender and race interests. While the research at hand builds upon the work of Bratton and Haynie, our work differs in that we disaggregate the legislators' race, gender, and party. We argue that by disaggregating the data, 
we ameliorate the potential pitfall of the ecological fallacy-the error of making false individual inferences from aggregate level data. Additionally, by examining each of these subgroups, we are able to make comparisons among groups, as well as across groups.

Finally, we question whether African American women experience a "double disadvantage" in terms of bill success. Women and politics scholars find that women are as likely as men to get their legislation passed (Bratton and Haynie 1999; Saint-Germain 1989; Thomas 1994). However, African American women report that their legislative experiences, once elected, differ substantially from their legislative counterparts (Barrett 1997; Hedge, Button and Spear 1996; Hawkesworth 2003). African American women describe a lower quality of legislative life than their African American male counterparts and are less optimistic about the influence of African Americans on the overall legislative agenda (Hedge, Button and Spear 1996). Further, informed by their experiences with racism and sexism in the legislature, Smooth (2001) finds that African American women state legislators, regardless of their leadership positions in the legislature, consider themselves alienated in the legislative institution. Hawkesworth (2003) argues that African American women in Congress face extreme marginalization as a pattern of "racegendering" practices that operate to construct African American women legislators as subordinates. These differences in legislative experiences are likely influenced by their experiences in navigating their legislation through the policymaking process. Hence, we further specify hypotheses 3 and 4 as follows:

Hypothesis 3: The likelihood of a progressive bill is expected to increase when an African American woman introduces a bill, than when other members of the legislature introduce a bill.

Hypothesis 4: A bill will be less likely to pass when an African American woman introduces a bill than when other members of the legislature introduce bills.

\section{DATA AND METHODS}

We test the aforementioned hypotheses by employing data collected from the state of Mississippi. While there are certainly limitations to a single case study, Mississippi has a number of characteristics that make it an ideal case to examine these questions regarding black political representation.
In 2001, Mississippi, with 892 black elected officials, ranked number one among states in both the actual numbers and the proportion of black elected officials and the state is currently second in the number of African Americans elected to the legislature (Bositis 2003). ${ }^{3}$ Further, Mississippi has traditionally served as a symbol of the Civil Rights movement and, as Parker (1990) argues, the state serves as a barometer of the movement's progress. Prior to the passage of the Voting Rights Act, African Americans had not served in the Mississippi congressional delegation or the state legislature since Reconstruction. By 1988, however, 22 African Americans (18 percent of the overall membership) gained seats in the state's house of representatives, and by 1999 this number had increased to 35 ( 29 percent out of a total of 122 representatives).

In studies of state legislative politics, it is often difficult to build generalizations across states, given the significant variations in the culture of state legislatures (Weissert 1989; Haynie 2002). While a comparative analysis of state legislatures would bolster our findings, much is gleaned from the analysis of Mississippi given its pivotal role in the development of black political participation. To buffer the effects of the one state sample, we include data from multiple legislative sessions.

Our data are culled from those substantive legislative proposals introduced during the 1988-1989 and 1998-1999 legislative sessions in the lower house of the Mississippi state legislature, excluding all commemorative and non-binding resolutions. We identified the bills introduced and passed during the 1988-1989 legislative session using the Mississippi House Journal Index, while the same data for the 1998-99 legislative session were obtained from the Mississippi Legislature Web site (http:// www.ls.state.ms.us). In addition, we gathered data from the Mississippi Official and Statistical Register to identify the party of each member, the years of legislative experience, and whether a member served as chair of a committee.

\section{Dependent Variables}

The unit of analysis is the individual bill. The purpose for choosing the individual bill as our unit of analysis hinges on our interest in examining the likelihood that a certain bill of interest will be introduced. Our dependent variable is the type of bill (e.g., black interest, women interest). This variable takes on a value of one if the policy area of interest is introduced and zero otherwise. Two coders performed the initial coding of the bills, and we subsequently included a third coder to check for reliability. After recoding 17 percent of the bills, we achieved an inter-coder reliability 
score of 98 percent, meaning that the coders agreed on 98 percent of the bills. Based upon the content of the bill, we coded each into the following six categories: black interests, women's interests, education policy, health care policy, children's policy, and welfare policy. These categories are also in keeping with those Barrett (1995) identifies as particular to African American women's legislative agendas, and model Bratton and Haynie's (1999) determinants of progressive black interest and women's interest legislation. It also should be noted that bills were not always mutually exclusive and were placed in multiple categories where appropriate. For example, a bill possessing both a children and welfare dimension or a women and health care dimension was coded as one for each dimension.

Specific examples of black interest bills include a bill that seeks government start-up funds to create minority owned businesses, a bill to create a civil rights monument commission, a bill to make July 4th Medgar Evers' Day, ${ }^{4}$ and a bill to require schools to offer African American history courses. Bills that were interpreted by the authors to be detrimental to blacks' or women's interests were not included in the analysis. For example, bills that attempted to eliminate or reduce funds for minorityowned businesses were not considered black interest bills.

\section{Independent Variables}

In the current analysis, we disaggregate the data according to race, gender, and party identification. In doing so, we create exhaustive categories (e.g., black female Democrats; black male Democrats; white female Democrats; white male Democrats; white female Republicans; and white male Republicans).$^{5}$ These variables are measured as dummy variables, and are coded 1 , if the category describes the legislator (and zero otherwise). White male Democrats are the reference group. The number of years a legislator has served in the legislature is measured in actual years. Harmel, Hamm, and Thompson (1983), conclude that legislators who hold positions of leadership tend to be more effective in the legislative process. Therefore, committee chairs are included in the model because they are perceived by their peers as having.legislative influence (Meyer 1980; Best 1971; Bell and Price 1975). Indeed, they introduce more legislation and are more likely to see that legislation passed (Frantzich 1979; 1980). Committee chair takes on a value of 1 if the legislator served as a committee chair during the legislative session of interest (and zero otherwise). Seniority is included in the model given the perception that senior members are more effective and influential in the passage of legislation (Hibbings 1991, 1993). Moreover, Hamm, Harmel, and Thompson (1983) contend that more senior members are more familiar with the legislative process and are more likely to be recognized for their expertise and to hold leadership positions (Hamm, Harmel, and Thompson 1983; Frantzich 1979, 1980; Meyer 1980). Seniority is measured as the number of consecutive years that a legislator served in office during the legislative session of interest. Lastly, in an effort to control for the potential of episodic events having an influence on the dependent variable, we control for the year in which the bill was introduced or passed.

We use logistic regression, as the dichotomous nature of the dependent variables renders ordinary least squares inappropriate. Since logit is a nonlinear procedure, the coefficients themselves are not easily interpretable; therefore, we present odds-ratios, given their ease of interpretation. Because we are again interested in the likelihood that a specific bill will be introduced (e.g., black interests, women's interests), the unit of analysis is the bill. ${ }^{6}$ Observations are independent across groups, but not necessarily independent within groups; therefore, we employ robust cluster standard errors ${ }^{7}$ in our estimation to protect against the attenuation of the standard errors due to the potential non-independence of observations within a group of bills sponsored by one legislator.

\section{FINDINGS}

The first stage of our analysis sets out to examine the likelihood that a progressive bill will be introduced. In accordance with Hypothesis 1 , the likelihood of a progressive bill being introduced is greatest when an African American serves as the primary sponsor of a bill. This finding holds in every policy area, save for Health Care. In addition, Hypothesis 3 is also confirmed. According to Table 1, the likelihood of a progressive bil being introduced is greatest when an African American woman introduces a bill.

Our analysis now turns to each of the policy issues examined. Table 1, Model 1, reports the results for the black interest model. According to this table, black interest bills are overwhelmingly more likely to be introduced when black legislators introduce bills, than when white male Democrats serve as the chief sponsor. The odds-ratios indicate that a black interest bill is roughly 21 times more likely to be introduced when a black female serves as chief sponsor, than it is when a white male 
TABLE 1. Logistic Regression Analysis: Effect of Legislators' Introduction of Progressive Bills

\begin{tabular}{|c|c|c|c|c|c|c|}
\hline & \multicolumn{6}{|c|}{$\begin{array}{c}\text { Models } \\
\text { (Odds Rations, Z Scores') }\end{array}$} \\
\hline & $\begin{array}{c}\text { (1) } \\
\text { Black } \\
\text { interest }\end{array}$ & $\begin{array}{c}(2) \\
\text { Women } \\
\text { interest }\end{array}$ & $\begin{array}{c}\text { (3) } \\
\text { Edicationi }\end{array}$ & $\begin{array}{c}\text { (4) } \\
\text { Wolfare }\end{array}$ & $\begin{array}{c}(5) \\
\text { Chitứren }\end{array}$ & $\begin{array}{c}(6) \\
\text { Health } \\
\text { Caie } \\
\end{array}$ \\
\hline $\begin{array}{c}\text { Black Female } \\
\text { Democrat }\end{array}$ & $\begin{array}{l}21.064 \\
(3.69)^{\star \star}\end{array}$ & $\begin{array}{l}7.321 \\
(4.29)^{n *}\end{array}$ & $\begin{array}{l}2.773 \\
(3.26)^{* *}\end{array}$ & $\begin{array}{l}6.858 \\
(3.68)^{\star *}\end{array}$ & $\begin{array}{l}3.028 \\
(2.58)^{\star *}\end{array}$ & $\begin{array}{l}1.173 \\
(0.51)\end{array}$ \\
\hline Black Male Democrat & $\begin{array}{l}18.840 \\
(5.65)^{\star \star}\end{array}$ & $\begin{array}{r}0.675 \\
(-0.69)\end{array}$ & $\begin{array}{l}1.514 \\
(1.57)\end{array}$ & $\begin{array}{l}1.260 \\
(0.48)\end{array}$ & $\begin{array}{r}0.842 \\
(-0.67)\end{array}$ & $\begin{array}{c}0.593 \\
(-1.85)\end{array}$ \\
\hline $\begin{array}{l}\text { White Male } \\
\text { Republican }\end{array}$ & $\begin{array}{l}1.482 \\
(0.51)\end{array}$ & $\begin{array}{c}0.477 \\
(-1.13)\end{array}$ & $\begin{array}{l}1.191 \\
(0.57)\end{array}$ & $\begin{array}{c}0.700 \\
(-0.51)\end{array}$ & $\begin{array}{r}0.760 \\
(-0.92)\end{array}$ & $\begin{array}{c}0.648 \\
(-1.16)\end{array}$ \\
\hline $\begin{array}{l}\text { White Female } \\
\text { Republican }\end{array}$ & & $\begin{array}{l}1.231 \\
(0.27)\end{array}$ & $\begin{array}{l}1.405 \\
(0.79)\end{array}$ & $\begin{array}{l}1.251 \\
(0.36)\end{array}$ & $\begin{array}{l}1.190 \\
(0.23)\end{array}$ & $\begin{array}{c}0.560 \\
(-1.52)\end{array}$ \\
\hline $\begin{array}{l}\text { White Female } \\
\text { Democrat }\end{array}$ & & & $\begin{array}{l}2.280 \\
(2.46)^{\star \star}\end{array}$ & $\begin{array}{l}1.091 \\
(0.13)\end{array}$ & $\begin{array}{l}1.885 \\
(1.53)\end{array}$ & $\begin{array}{l}1.270 \\
(0.92)\end{array}$ \\
\hline 1989 & $\begin{array}{c}0.630 \\
(-1.36)\end{array}$ & $\begin{array}{l}1.155 \\
(0.58)\end{array}$ & $\begin{array}{l}1.032 \\
(0.17)\end{array}$ & $\begin{array}{l}2.495 \\
(3.08)^{* *}\end{array}$ & $\begin{array}{l}2.460 \\
(3.41)^{\star *}\end{array}$ & $\begin{array}{l}1.359 \\
(1.55)\end{array}$ \\
\hline 1998 & $\begin{array}{c}0.411 \\
(-1.77)\end{array}$ & $\begin{array}{c}1.344 \\
(0.71)\end{array}$ & $\begin{array}{c}0.945 \\
(-0.23)\end{array}$ & $\begin{array}{c}0.797 \\
(-0.49)\end{array}$ & $\begin{array}{l}2.092 \\
(2.57)^{\star \star}\end{array}$ & $\begin{array}{l}1.998 \\
(1.89)\end{array}$ \\
\hline 1999 & $\begin{array}{r}0.548 \\
(-1.46)\end{array}$ & $\begin{array}{c}0.833 \\
(-0.40)\end{array}$ & $\begin{array}{c}0.726 \\
(-1.17)\end{array}$ & $\begin{array}{l}1.784 \\
(1.11)\end{array}$ & $\begin{array}{l}3.016 \\
(4.11)^{\star \star}\end{array}$ & $\begin{array}{l}1.572 \\
(1.19)\end{array}$ \\
\hline Chair & $\begin{array}{c}0.559 \\
(-1.00)\end{array}$ & $\begin{array}{l}0.803 \\
(-0.61)\end{array}$ & $\begin{array}{l}1.118 \\
(0.55)\end{array}$ & $\begin{array}{c}0.838 \\
(-0.46)\end{array}$ & $\begin{array}{c}0.782 \\
(-1.15)\end{array}$ & $\begin{array}{l}1.251 \\
(0.92)\end{array}$ \\
\hline Seniority & $\begin{array}{l}1.032 \\
(0.82)\end{array}$ & $\begin{array}{c}0.993 \\
(-0.20)\end{array}$ & $\begin{array}{c}0.965 \\
(-1.45) \\
\end{array}$ & $\begin{array}{l}1.028 \\
(1.37)^{\star *}\end{array}$ & $\begin{array}{r}0.997 \\
(-0.16)\end{array}$ & $\begin{array}{l}0.994 \\
(-0.41)\end{array}$ \\
\hline$N$ & 6157 & 6691 & 6692 & 6691 & 6693 & 6693 \\
\hline Pseudo $\mathrm{R}^{2}$ & .15 & .07 & .02 & .05 & .04 & .02 \\
\hline Model $X^{2}$ & $46.80^{* *}$ & $106.20^{\star \star}$ & $29.72^{* *}$ & $48.94^{\star \star}$ & $34.46^{\star *}$ & $29.87^{* * *}$ \\
\hline
\end{tabular}

Robust $z$ statistics in parentheses

* Significant at $p<.05 ;{ }^{\star \star}$ Significant at $p<.01$

Democrat introduces a bill. To a slightly lesser degree, the likelihood of a black interest bill being introduced is roughly 19 times more likely to be introduced when a black male introduces a bill, than when a white male Democrat introduces a bill. There is no significant difference between white male Republicans and white male Democrats. Since no white women introduced any black interest bills, they are excluded from the analysis.

We also find that women's interest bills are more likely to be introduced when black women serve as the key sponsors of a bill, as compared to when a white male Democrat introduces a bill. Based on the findings in Model 2, a women's interest bill is approximately seven times more likely to be introduced when a black woman introduces a bill, than when her white male counterpart introduces a bill. Surprisingly, neither white female Democrats nor white female Republicans are any, more likely to introduce women's interest bills when compared to their white male Democratic colleagues. In fact, white female Democrats failed to introduce any legislation relating to women's issues during the scope of this analysis.

Model 3 illustrates that a bill is more likely to be an education bill when either a black or white female Democrat sponsors a bill. Based on the findings, a bill is 2.8 times more likely to be an education bill when a black female Democrat introduces a bill, as opposed to a white male Democrat.

The results in Model 4 reveal that black female Democrats stand alone in outperforming white male Democrats in enhancing the likelihood of welfare legislation being introduced. The model also reveals that seniority increases the likelihood of legislators introducing welfare bills. Moreover, according to Model 5, a bill is more likely to be a children's interest bill when a black woman serves as the primary sponsor. Finally, Model 6 illustrates that none of the groups were significantly different than white male Democrats in introducing bills related to health care.

In addition to analyzing the bills that were introduced, we also are interested in examining how African American men and women fared in successfully passing legislation when compared to their colleagues in the legislature. Again, the findings are mixed. Based on Table 2, only black male Democrats were significantly less likely to pass legislation when compared to their white male counterparts, thereby providing only partial support for Hypothesis 2. More importantly, however, is the fact that Hypothesis 4 is rejected: black women are not significantly less likely to pass legislation when compared to their white male colleagues. ${ }^{8}$ This is a major unexpected finding because it counters the notion that, due to race and gender, African American women will be less successful in representing their constituents. In sum, black women are more likely to submit legislation that will benefit their constituents and their bills are not guaranteed to fail. 
TABLE 2. Logistic Regression Analysis: Effect of Legislators on Bill Passage

\begin{tabular}{lc}
\hline & $\begin{array}{c}\text { Passed } \\
\left.\text { (Odds Ratios, Z Scores }{ }^{2}\right)\end{array}$ \\
\hline Black Female Democrat & $0.406(-1.17)$ \\
Black Male Democrat & $0.610(-2.31)^{*}$ \\
White Mále Reputiticail & $0.817(-0.71)$ \\
White Female Republican & $0.973(-0.06)$ \\
White Female Democrat & $1.209(0.70)$ \\
1989 & $0.599(-4.49)^{* *}$ \\
1998 & $0.474(-4.40)^{* *}$ \\
1999 & $0.547(-3.15)^{* *}$ \\
Chair & $0.853(-0.76)$ \\
Seniority & $1.051(3.61)^{* *}$ \\
\hline$N$ & 6695 \\
Pseudo $R^{2}$ & .03 \\
Model $X^{2}$ & 58.11 \\
\hline
\end{tabular}

a Robust $z$ statistics in parentheses

${ }^{\star}$ Significant at $p<.05 ;{ }^{\star \star}$ Significant at $p<.01$

\section{CONCLUSION}

Our analysis builds on previous work on legislative policymaking, but by disaggregating legislators by race, gender, and political party, we add greater specification to models of legislative representation and extend the literature. We find that important differences exist not only across racial groups but also among racial groups. In keeping with previous studies, we find that African American men and women are responsible for introducing more progressive legislation. Yet, when we disaggregate African American men and women, we find that a progressive bill is more likely to be introduced when a black woman serves as the primary sponsor. Arguably, because African American women are "doubly disadvantaged," as a result of both racism and sexism, they possess unique perspectives when compared to their peers, which informs their legislative agendas. These unique perspectives result in a legislative commitment to representing the interests of both African Americans and women, essentially building a liberal-based agenda. While African American women were most likely to introduce women's interest bills, surprisingly, among Democrats, white women were no more likely than white men to introduce women's interest bills as is also the case for Republican women. Moreover, African American women were slightly more likely than black men to introduce black interest bills. These findings substantiate earlier claims that African American women are best examined as a separate political category.

Our findings also run counter to earlier findings in the literature that suggest that African Americans are less successful in passing legislation. To the contrary, we find that African American women legislators' bills were not guaranteed to fail. These findings do restore some confidence in democratic institutions, in that they suggest that, regardless of the race or gender of legislators, they can effectively represent the interests of their constituents. Yet, we do not suggest that a legislator's race and gender are irrelevant in state legislative policymaking. Additional research is needed to determine the conditions under which race and gender impact bill passage. Perhaps further research regarding the impact of the numbers of women and people of color on bill passage is warranted Indeed, the Mississippi case suggests that numbers may play a role in the ability of women and legislators of color to represent effectively their interests.

We certainly acknowledge potential limitations of this study. in that our study analyzes only one house of the legislature of one state over time. As a result of using one case, this study could lack external validity. We assert, however, that Mississippi serves as the best case for the analysis of the performance of African American legislators because the state led the country in number of African American legislators. As greater emphasis is placed on increasing the number of women and people of color in elected office, the Mississippi case allows us a glimpse into how these legislators will fare as their numbers increase. While this study offers an initial examination of the legislative behavior of women and African Americans, additional research is needed to discern these legislators' behaviors under varying circumstances.

Taken together, the strongest message of these findings is the need to specify models in which difference is recognized within groups, not just between groups as in the differences between blacks and whites or men and women in policymaking. This research supports the notion that intragroup differences matter and must be taken into account in constructing models of legislative behavior. The findings here strongly encourage us to re-examine claims that "women" as a group are more likely to represent women's interests. Instead, we must question which women are more likely to represent women's interests. Indeed, the same is true for 
who is representing African American interests. Scholars of black feminism have long argued the specificities of black women's lives and the differences that gender plays in their experiences, concluding that they experience the world quite differently from their male counterparts. Here, we find that this is also the case in the policymaking process.

African American women are a group with specialized interests. The same is likely true for other women of color. As the number of women of color rises in legislative bodies, we will need to construct models that are more attentive to these differences. As this study reveals, accuracy in presenting the legislative process will depend on our abilities to construct models that take into account the intersections of race and gender and recognize the complexities of such intersections.

\section{ACKNOWLEDGMENTS}

An earlier version of this article was presented at the National Conference of Black Political Scientists Annual Conference in Chicago, Ilinois, March 25-27, 2004. The authors are especially thankful to Charles E. Jones and Robert Albritton for their prior comments and Daniel Bratten for his research assistance. The first author is especially thankful to Lisa McBride for her data assistance, the Senning Foundation for its financial support and to the late Dan Orey, Jr., for his practical advice. Of course, only the authors can be responsible for the analyses and interpretations presented here.

\section{NOTES}

1. According to David Bositis (1999), Mississippi led the nation in the number of black elected officials in 1998, with 849 black elected officials, followed by Alabama (733), Louisiana (666), Illinois (626), Georgia (597), South Carolina (554), North Carolina (513), Arkansas (482), Texas (474), Michigan (348), and Virginia (333).

2. We choose 1988-89 and 1998-1999 for a number of reasons. First, while Thornburg $v$ Gingles was significant in increasing the number of black elected officials, the impact of this case would not come into fruition until the post 1990 redistricting cycle. Following this cycle we saw a vast increase in the number of black state legislators. Hence, here we are able to control for years prior to this increase and years immediately following this increase.

3. Unitil 2001, Mississippi ranked number one in the number of black state legislators. Between 2000 and 2001, Georgia gained four black legislators, ranking it as number one with a total of 47 black legislators. Mississippi follows with 45 black state legislators.

4. Medgar Evers was a slain civil rights activist, who served as Mississippi's first full time field secretary for the National Association for the Advancement of Colored People
(NAACP), the leading civil rights organizing group in the state during the height of the movement (Dittmer 1995).

5. African American legislators are all Democrats in the state of Mississippi.

6. In a separate analysis, we aggregate each bill using the legislator as the unit of analysis. Those findings are consistent with the findings presented here. In other words, we take each bill that was introduced by a single legislator and record the number of progressive bills introduced by that legislator. So, now, -rather than code whether a legislator introduced a progressive bill as I (and zero otherwise), we simply add up the number of progressive bills introduced by that legislator and record that number. If $\mathrm{s} / \mathrm{h}$ introduced eight bills we would simply record eight progressive bills for that legislator, thus, making the legislator the unit of analysis.

7. These are a generalization of White's (1980) robust standard errors (see Greene 1997).

8. For parsimonious purposes, and problems with small sample sizes, we have aggregated all of the bills of interest into one model. These findings are consistent with individual analyses of each of the policy areas (e.g., black interests, women's interests) save for children's interest bills. Black women are significantly less likely to pass children's interest bills when compared to their white male counterparts.

\section{REFERENCES}

Barrett, Edith J. 1995. "The Policy Priorities of African American Women in State Legislatures:" Legislative Studies Quarterly 20(2): 223-47.

. 1997. "Gender and Race in the State House: The Legislative Experience." Social Science Journal 34(2): 131-44.

Baxter, Sandra, and Marjorie Lansing. 1980. Women and Politics: The Invisible Majority. Ann Arbor: University of Michigan Press.

Bell, Charles G., and Charles M. Price. 1975. The First Term: A Study of Legislative Socialization. Beverly Hills, CA: Sage Publications.

Best, James J. 1971. "Influence in the Washington House of Representatives." Midwest Journal of Political Science 15: 547-62.

Bositis, David. 1999. "Trendletter: Black Elected Officials, 1998." Focus Magazine. Washington, DC: Joint Center for Political and Economic Studies.

2001. The Black Vote in 2000. Washington, DC: Joint Center for Political and Economic Studies.

2003. Black Elected Officials: A Statistical Summary 2001. Washington, DC Joint Center for Political and Economic Studies.

Brady, Henry, and Paul M, Sniderman. 1985. "Attitude Attribution: A Group Basis for Political Reasoning." American Political Science Review 79: 1061-78.

Bratton, Kathleen, and Kerry Haynie. 1999. "Agenda Setting and Legislative Success in State Legislatures: The Effects of Gender and Race." Joumal of Politics 61(3) 658-79.

Carroll, Susan. J. 2002. "Representing Women: Congresswomen's Perceptions of Their Representational Roles." In Women Transforming Congress, ed. Cindy Simon Rosenthal. Norman, OK: University of Oklahoma Press. 
Carroll, Susan J., Debra Dodson, and Ruth Mandel. 1991. The Impact of Women in Office: An Overview. New Brunswick, NJ: Center for American Women and Politics.

Collins, Patricia Hill. 1990. Black Feminist Thought: Knowledge, Consciousness and the Politics of Empowerment. New York: Routledge.

2000. Black Feminist Thought: Knowledge, Consciousness and the Politics of Empowerment. 2nd ed. New York: Routledge.

Crenshaw, Kimberlé. 1991. "Mapping the Margins: Intersectionality, Identity Politics and Violence Against Women of Color." Stanford Law Review 43(6): 1241-99.

Darcy, Robert, and Charles Hadley. 1988. "Black Women in Politics: The Puzzle of Success." Social Science Quarterly 77(4): 888-98.

Dawson, Michael. 1994. Behind the Mule: Race and Class in African American Politics. Princeton, NJ: Princeton University Press.

Dittmer, John. 1994. Local People: The Struggle for Civil Rights in Mississippi. Chicago: University of Illinois Press.

Frantzich, Stephen E. 1979. "Who Makes Our Laws? The Legislative Effectiveness of Members of the U.S. Congress." Legislative Studies Quarterly 4: 409-28.

1980. "Who Makes Our Laws? The Power of Individual Members of the U.S. Senate." Paper delivered at the Annual Meeting of the American Political Science Association, Washington, DC.

Greene, William H. 1997. Econometric Analysis. 3rd ed. Upper Saddle River, NJ: Prentice Hall.

Hacker, Andrew. 1992. Two Nations: Black and White, Separate, Hostile, Unequal. New York: Scribner's.

Hamm, Keith E., Robert Harmel, and Robert Thompson. 1983 "Ethnic and Partisan Minorities in Two Southern State Legislatures." Legislative Studies Quarterly $8(2): 177-89$.

Harmel, Robert, Keith Hamm, and Robert Thompson. 1983. "Black Voting Cohesion and Distinctiveness in Three Southern Legislatures." Social Science Quarterly 64: 183-92.

Hawkesworth, Mary. 2003. "Congressional Enactments of Race-Gender: Toward a Theory of Race-Gendered Institutions." American Political Science Review 97(4): 529-50.

Haynie, Kerry. 2001. African American Legislators in the American States. New York: Columbia University Press.

Hedge, David, James Button, and Mary Spear. 1996. "Accounting for the Quality of Black Legislative Life: The View From the States." American Journal of Political Science 40: 82-98.

Hibbings, John. 1993. "Careerism in Congress." In Congress Reconsidered, ed. Lawrence C. Dodd and Bruce I. Oppenheimer. Washington, DC: Congressional Quarterly Press.

1991. Congressional Careers: Contours of Life in the U.S. House of Representatives. Chapel Hill: University of North Carolina Press.

Hull, Gloria T., Patricia Bell Scott, and Barbara Smith. 1982. All the Women are White, All the Blacks are Men, But Some of Us Are Brave. New York: Feminist Press.

Kahn, Katherine L., Majorie L. Pearson, Ellen R. Harrison, Katherine A. Desmond, William H. Rogers, Lisa V. Rubenstein, Robert H. Brook, and Emmett B. Keeler. 1994. "Health Care for Blacks and Poor Hospitalized Medicare Patients." Journal of the American Medical Association 271(15): 1169-74.
Kathlene, Lyn. 1994. "Power and Influence in State Legislative Policymaking: The Interaction of Gender and Position in Committee Hearing Debates." American Political Science Review 88(3): 560-76.

1995. “Position Power versus Gender Power: Who Holds the Floor?" In Gender Power, Leadership and Governance, ed. Georgia Duerst-Lahti and Rita Mae Kelly. Ann Arbor: University of Michigan Press.

Kinder, Donald R. 1994. "Reason and Emotion in American Political Life." In Beliefs, Reasoning, and Decision-Making: Psycho-Logic in Honor of Bob Abelson, ed. Roger C. Schank and Elleñ Lânger. Hillsuale, NJJ: Läwînence Eribaum Ássociates.

King, Deborah K. 1988. "Multiple Jeopardy, Multiple Consciousness: The Context of a Black Feminist Ideology." Signs 14(Autumn): 42-72.

Lorde, Audre, 1984 "Age, Race, Class and Sex: Women Redefining Difference." In Sister Outsider Essays and Speeches. Berkeley, CA: Crossing Press [a division of Ten Speed Press], 114-123.

Mansbridge, Jane, 1999. "Should Blacks Represent Blacks and Women Represent Women? A Contingent "Yes'." Journal of Politics 61(3): 628-57.

Massey, Douglas S., and Nancy A. Denton. 1993. American Apartheid: Segregation and the Making of the Underclass. Cambridge, MA: Harvard University Press.

Meyer, Katherine. 1980. "Legislative Influence: Toward Theory Development through Causal Analysis.” Legislative Studies Quarterly 5: 563-85.

Miller, Cheryl M. 1990. "Agenda Setting by State Legislative Black Caucuses: Policy Priorities and Factors of Success." Policy Studies Review 9(2): 339-54.

Mississippi House Journal Index. 1989. Journal of the House of Representatives of the State of Mississippi. One Hundred and Fourth Session.

Mississippi House Joumal Index. 1999. Journal of the House of Representatives of the State of Mississippi. One Hundred and Fourteenth Session. Downloaded from http:// billstatus.ls.state.ms.us $/ 2001 / \mathrm{html} / \mathrm{h}$ auth.html

Mississippi Secretary of State Office, 1989. Official and Statistical Register, 1988-1992.

Moncrief, Gary, Joel Thompson, and Robert Schulmann. 1991. "Gender, Race and the State Legislature: A Research Note on the Double Disadvantage Hypothesis," Social Science Journal 28:481-87.

Nelson, Albert J. 1991. Emerging Influentials in State Legislatures: Women, Blacks, and Hispanics. New York: Praeger.

Norton, Noelle. 1995. "Women, It's Not Enough to be Elected: Committee Position Makes a Difference." In Gender Power, Leadership and Governance, ed. Georgia DuerstLahti and Rita Mae Kelly, 115-40. Ann Arbor: University of Michigan Press.

Orey, Byron D'Andra. 2000. "Black Legislative Politics in Mississippi." Journal of Black Studies 30(6): 791-814.

Parker, Frank. 1990. Black Votes Count: Political Empowerment in Mississippi after 1965. Chapel Hill: University of North Carolina Press.

Pitkin, Hannah. 1967. The Concept of Representation. Berkeley, CA: University of California Press.

Prestage, Jewell. 1977. "Black Women State Legislators: A Profile. In A Portrait of Marginality The Political Behavior of the American Woman, ed. Mary Githens and Jewell Prestage. 
Reingold, Beth. 2000. Representing Women: Sex, Gender and Legislative Behavior in Arizona and California. Chapel Hill: University of North Carolina Press.

Rosenthal, Cindy Simon. 1998. When Women Lead: Interactive Leadership in State Legislatures. New York: Oxford University Press.

Saint-Germain, Michelle A. 1989. "Does Their Difference Make a Difference? The Impact of Women on Public Policy in the Arizona State Legislature." Social Science Quarterly 70: 756-70.

Sanbonmatsu, Kira. 2005. "State Elections: Where Do Women Run: Where Do Women Win?' In Gender and Elections in America: Shaping the Future of American Politics, ed. Susan J. Carroll and Richard Fox. New York: Cambridge University Press.

Sokolow, Alvin D. 1971. "Black Members-White Legislators." Black Politician 2: 23-30.

Shapiro, Robert Y., and Harpreet Mahajan. 1986. "Gender Differences in Policy Preferences: A Summary of Trends from the 1960s to the 1980s." Public Opinion Quarterly 50(1): 42-61.

Smooth, Wendy G. 2001. "African American Women State Legislators and the Politics of Legislative Incorporation." Monograph. Prepared for the Center for American Women and Politics Forum for Women State Legislators, November 15-18.

2005. "African American Women and Electoral Politics: Journeying from the Shadows to the Spotlight" In Gender and Elections in America: Shaping the Future of American Politics, ed. Susan J. Carroll and Richard Fox. New York: Cambridge University Press.

Swain, Carol M. 1993. Black Faces, Black Interests: The Representation of African Americans in Congress. Cambridge, MA: Harvard University Press.

Sribney, Bill. 1997. "Stata Help for Logit." www.stata.com/support/faq̨s/stat/svyml. html

Swers, Michelle. 2002. The Difference Women Make. Chicago: University of Chicago Press.

Tamerius, Karin L. 1995. "Sex. Gender, and Leadership in the Representation of Women." In Gender, Power, Leadership, and Governance, ed. Georgia Duerst-Lahti and Rita Mae Kelly. Ann Arbor: University of Michigan Press.

Tate, Katherine. 1993. From Protest to Politics: The New Black Voters in American Elections. Cambridge, MA: Harvard University Press.

2004. Black Faces in the Mirror: African Americans and their Representatives in Congress. Princeton, NJ: Princeton University Press.

Thomas, Sue. 1994. How Women Legislate. New York: Oxford University Press.

Thomas, Sue, and Susan Welch. 1991. "The Impact of Gender on Activities and Priorities of State Legislators. Western Political Quarterly 44: 445-56.

Weissert, Carol. 1991. "Determinants and Outcomes of State Legislative Effectiveness." Social Science Quarterly 72 (December): 797-806.

White, Halbert. 1980. "A Heteroscedasticity-Consistent Covariance Matrix and a Direct Test for Heteroscedasticity." Econometrica 48: 817-38.

Whitby, Kenny. 1998. The Color of Representation: Congressional Behavior and Black Interests. Ann Arbor: University of Michigan Press.
Williams, David R., and Chiquita Collins. 1996. "U.S. Socioeconomic and Racial Differences in Health: Patterns and Explanations." In Perspectives of Medical Sociology, ed. Phil Brown. 2d ed. Prospect Heights, IL: Weaveland Press.

Williams, Linda Faye. 2001. "The Civil Rights-Black Power Legacy: Black Women Elected Officials at the Local, State, and National Levels." In Sisters in the Struggle. African American Women in the Civil Rights-Black Power Movement, ed. Bettye Collier-Thomas and V.P. Franklin. New York: New-York University Press.

Woods, Nancy Fugate.1996. "Women and their Health." In Perspectives in Medical Sociology, ed. Phil Brown. 2nd ed. Prospect Heights, IL: Weaveland Press.

$$
\text { doi:10.1300/J501v28n03_05 }
$$

